\title{
Factors affecting anxiety levels of students of the Bachelor of Medicine Study Program and the Doctor's Profession, Faculty of Medicine, Udayana University Class of 2018-2020 in Undertaking the Online Lecture Learning System During the COVID-19 Pandemic
}

Fatores que afetam os níveis de ansiedade de alunos do Programa de Estudo de Bacharelado em Medicina e da Profissão de Doutor da Faculdade de Medicina da Udayana University Turma de 2018-2020 em Realização do Sistema de Aprendizagem de Palestra Online Durante a Pandemia de COVID-19

Factores que afectan los niveles de ansiedad de los estudiantes del Programa de estudios de Licenciatura en Medicina y la Facultad de Medicina de la Profesión de Doctor, Clase de la Universidad de Udayana de 2018-2020 en la realización del sistema de aprendizaje de conferencias en línea durante la pandemia COVID-19

Received: 12/16/2021 | Reviewed: 12/27/2021 | Accept: 01/01/2022 | Published: 01/02/2022

I Putu Divanaya Suryanov ORCID: https://orcid.org/0000-0002-5323-4826 Medical Faculty Udayana University, Indonesia E-mail: productiveduringcorona@gmail.com

I Gde Haryo Ganesha ORCID: https://orcid.org/0000-0002-0173-2057 Medical Faculty Udayana University, Indonesia E-mail: gdeganesha@gmail.com

Cokorda Agung Wahyu Purnamasidhi ORCID: https://orcid.org/0000-0002-1646-3793 Medical Faculty Udayana University, Indonesia E-mail: purnamasidhi@unud.ac.id

\begin{abstract}
Throughout the pandemic of COVID-19, medical students have been undergoing online learning, which has the potential to cause them anxiety. The study's objective is to determine a relationship between anxiety scales and gender, year of study, resilience scale, and social support scale. This study used a cross-sectional approach with analytic observational methodology. The year of study and gender were in the biodata section, the resilience scale was calculated utilizing the Nicholson McBride Resilience Questionnaire (NMRQ), and the social support scale was calculated utilizing the Oslo Social Support Scale-3 (OSSS-3). The Beck Anxiety Inventory (BAI) was employed to evaluate anxiety scales. The data was examined utilizing univariate and bivariate methods such as Chi-square and Kendall-tau. The amount of respondents was 238 respondents who were selected by simple random sampling. The result showed significant results $(p<0.05)$ for factors that consist of gender $(r=0.183, p<0.01)$, year of study $(r=-0.151, p<0.05)$, resilience $(r=-0.297$, $\mathrm{p}<0.01)$ and social support $(\mathrm{r}=-0.243, \mathrm{p}<0.01)$. This research's findings are gender, year of study, resilience, and social support all have a significant correlation with anxiety scale experienced by respondents while participating in online learning.
\end{abstract}

Keywords: Anxiety; Online learning; Gender; Year of study; Resilience; Social support; Teaching.

\section{Resumo}

Durante a pandemia de COVID-19, estudantes de medicina passaram por aprendizado online, o que pode causar ansiedade. O objetivo deste estudo é determinar se existe ou não relação entre os níveis de ansiedade e sexo, ano de estudo, nível de resiliência e nível de suporte social. Este estudo utilizou uma abordagem transversal com metodologia analítica observacional. $\mathrm{O}$ ano de estudo e o gênero foram medidos na seção de dados biológicos, o nível de resiliência foi medido usando o Nicholson McBride Resilience Questionnaire (NMRQ) e o nível de suporte social foi medido usando a Oslo Social Support Scale-3 (OSSS-3) . O Beck Anxiety Inventory (BAI) foi utilizado para avaliar os níveis 
de ansiedade. Os dados foram analisados por meio de métodos univariados e bivariados, como qui-quadrado e Kendalltau. O número de entrevistados foi de 238 entrevistados que foram selecionados por amostragem aleatória simples. O resultado mostrou resultados significativos $(\mathrm{p}<0,05)$ para fatores que consistem em gênero $(\mathrm{r}=0,183, \mathrm{p}<0,01)$, ano de estudo $(r=-0,151, p<0,05)$, resiliência $(r=-0,297, p<0,01)$ e suporte social $(r=-0,243, p<0,01)$. De acordo com os resultados deste estudo, sexo, ano de estudo, resiliência e suporte social têm uma relação significativa com o nível de ansiedade experimentado pelos entrevistados durante a participação no aprendizado online.

Palavras-chave: Ansiedade; Aprendizagem online; Gênero; Ano de estudo; Resiliência; Suporte social; Ensino.

\section{Resumen}

Durante la pandemia de COVID-19, los estudiantes de medicina han estado en aprendizaje en línea, lo que tiene el potencial de causarles ansiedad. El objetivo de este estudio es determinar si existe o no relación entre los niveles de ansiedad y el género, año de estudio, nivel de resiliencia y nivel de apoyo social. Este estudio utilizó un enfoque transversal con metodología observacional analítica. El año de estudio y el género se midieron en la sección de biodatos, el nivel de resiliencia se midió mediante el Nicholson McBride Resilience Questionnaire (NMRQ) y el nivel de apoyo social se midió mediante la Oslo Social Support Scale-3 (OSSS-3). Se utilizó el Beck Anxiety Inventory (BAI) para evaluar los niveles de ansiedad. Los datos se analizaron utilizando métodos univariados y bivariados como Chi-cuadrado y Kendall-tau. El número de encuestados fue de 238 encuestados que fueron seleccionados por muestreo aleatorio simple. El resultado mostró resultados significativos $(\mathrm{p}<0.05)$ para factores que consisten en género $(\mathrm{r}=0.183, \mathrm{p}<0.01)$, año de estudio $(r=-0.151, p<0.05)$, resiliencia $(r=-0.297, p<0.01)$ y apoyo social $(r=-0,243, p<0,01)$. Según los hallazgos de este estudio, el género, el año de estudio, la resiliencia y el apoyo social tienen una relación significativa con el nivel de ansiedad experimentado por los encuestados mientras participan en el aprendizaje en línea.

Palabras clave: Ansiedad; Aprender en línea; Género; Año de estudio; Resiliencia; Apoyo social; Enseñando.

\section{Introduction}

Online learning is a form of learning that uses smartphones, tablets, and laptops as a medium of interaction for medical students and teaching lecturers aimed at preventing the transmission of COVID-19 (Sari, 2020). At first, online learning seemed fun because there was no reason to spend time on preparation and travel both to school and to campus. However, after months of online learning, medical students tend to feel bored. This is because of a lack of social interaction with peers and lecturers, a deficiency in exercise, and excessive staring at the device. Furthermore, some students face challenges in online learning, such as insufficient gadgets and internet access, and also an absence of focus when studying from home. Moreover, being bored, they usually are concerned about a lot of things, including their finances, graduation, and daily life (Lasheras et al., 2020). Medical students may become anxious resulting from them. Anxiety is a common mood state in preparation for negative things (Hirsch et al., 2013). Normal anxiety can certainly assist someone in solving the problems he faces. Abnormal anxiety will interfere with a life of an individual by reducing concentration and focus by increasing thoughts filled with a bunch of terror and fear (Stuart, 2014).

The factors studied were gender, year of study, resilience, and social support. Year of study is the length of number of years of college that students have taken in an educational institution (Papilaya \& Huliselan, 2016). Gender is the level that can distinguish a person as male or female (Damayanti, 2012). Resilience is known as the ability of a person to maintain his psychological state when confronted with hardship (Poudel-Tandukar et al., 2019). Social support is as an acceptance of feeling of safety and appreciation for assistance received from others is a positive factor in someone's mental health (Harandi, Taghinasab, \& Nayeri, 2017). The aim of the research is to see whether there is a correlation between the variables studied and the anxiety scale in students of the Bachelor of Medicine and Medical Profession Study Program, Faculty of Medicine, Udayana University that could be summarized as Medical Students of Udayana University participating in a system of online education.

\section{Research Methods}

The following research took a cross-sectional design and analytic observational methodology. There were 238 medical students from Udayana University's Class of 2018-2020 who responded. Gender, year of study, resilience scale, and social 
support scale are the study's independent variables. Meanwhile, the anxiety scale is the study's dependent variable. The SPSS version 20 software was previously utilized to analyze the data. The data analysis methods used were univariate analysis and bivariate analysis. The function of univariate analysis is to identify the variables' characteristics. Bivariate analysis using the Chi-square and Kendall-tau methods to ascertain the existence and strength of a relationship between the independent variable and the dependent variable.

Data on anxiety-related factors were obtained as with a variety of ways: year of study and gender in the biodata section, resilience scale was calculated utilizing by Nicholson McBride Resilience Questionnaire (NMRQ), social support scale was calculated utilizing the the Oslo Social Support Scale-3 (OSSS-3) questionnaire, and anxiety scale was calculated utilizing Beck Anxiety. Inventory (BAI). The resilience scale in the NMRQ consists of 12 questions with the following interpretation: 0-37 for developing resilience (low), 38-43 for stable resilience (moderate), 44-48 for strong resilience (good), and 49-60 for very strong resilience (Ahuja et al., 2020). The resilience scale was categorized into two groups in the bivariate analysis, and they are as follows: the low resilience group with a total value range of 0-37 (developing resilience) and high resilience with a range of different of 38-60 values (stable to exceptional resilience). The social support scale was examined using OSSS-3 with a total score range of 3-14 with the following interpretation. 3-8 for a poor social support scale, 9-11 for a moderate social support scale, and 12-14 for a good social support scale (Kocalevent et al., 2018). In the bivariate analysis, the social support scale was divided into two groups, which are as follows: a low social support scale (poor social support) group with a score range of 3-8, and a high social support scale group with a score range of 9-14 (moderate to good social support). The anxiety scale was assessed using BAI with a total of 21 questions with a score of 0-3 on each number and a total score of 0-63. BAI value range can be interpreted as follows: 0-9 for no anxiety or normal anxiety, 10-18 for mild to moderate anxiety, 19-29 for moderate to severe anxiety, and a range of 30-63 for severe anxiety) (Lee, Kim, \& Cho, 2018). The anxiety scale was grouped into two categories in the bivariate analysis: normal anxiety scale with a value range of 0-9 and abnormal anxiety scale with a value range of 10-63 (moderate to severe anxiety scale).

\section{Results}

This following research was done between April and May of 2021.with 238 respondents from the Medical Students of Udayana University's Class of 2018-2020. According to Table 1, most respondents were under the age of 20. The majority of the respondents were female. Respondents were mostly from first-year students. Respondents' resilience was most stable. Respondents' average social support scale was moderate. Respondents' anxiety scale were mostly consisting of normal anxiety. 
Research, Society and Development, v. 11, n. 1, e9011124804, 2022

(CC BY 4.0) | ISSN 2525-3409 | DOI: http://dx.doi.org/10.33448/rsd-v11i1.24804

Table 1. Characteristics of Research Respondents.

\begin{tabular}{|c|c|}
\hline Variables & n $(\%)$ \\
\hline \multicolumn{2}{|l|}{ Age } \\
\hline$<20$ & $124(51,9)$ \\
\hline$\geq 20$ & $114(47,7)$ \\
\hline \multicolumn{2}{|l|}{ Gender } \\
\hline Male & $89(37,4)$ \\
\hline Female & $149(62,6)$ \\
\hline \multicolumn{2}{|l|}{ Year of study } \\
\hline First & $93(39,1)$ \\
\hline Second & $66(27,7)$ \\
\hline Third & $79(33,2)$ \\
\hline \multicolumn{2}{|l|}{ Resilience scale } \\
\hline Developing & $73(30,7)$ \\
\hline Established & $93(39,1)$ \\
\hline Strong & $45(18,9)$ \\
\hline Exceptional & $27(11,3)$ \\
\hline \multicolumn{2}{|l|}{ Social support scale } \\
\hline Poor & $59(24,8)$ \\
\hline Moderate & $126(52,9)$ \\
\hline Strong & $53(22,3)$ \\
\hline \multicolumn{2}{|l|}{ Anxiety scale } \\
\hline Normal & $167(70,2)$ \\
\hline Mild to moderate & $29(12,2)$ \\
\hline Moderate to severe & $42(17,6)$ \\
\hline Severe & $0(0)$ \\
\hline
\end{tabular}

Note: $\mathrm{n}(\%)=$ sum and percentagem. Source: Authors (2021).

The factors of resilience scale, social support scale, and anxiety scale were categorized into two groups in the bivariate test. The resilience scale was grouped into two categories: low resilience (developing resilience) and high resilience (stable to exceptional resilience). The social support scale was categorized into two groups: individuals with low social support (poor social support) and individuals with high social support (moderate to strong social support). Anxiety scales were grouped into two categories: normal anxiety scale and abnormal anxiety scale (moderate to severe anxiety scales). According to Table 2, the chi-square test results revealed that gender, year of study, resilience, and social support, had a significant relationship with anxiety scale $(p<0,05)$. From the gender factor, men experienced the most normal anxiety and women experienced the most abnormal anxiety. Respondents tend to experience abnormal anxiety in year of study factor; however, There are variations in the range of anxiety scales between groups that are getting shorter from first-year respondents to third-year respondents. Respondents with low resilience scale tend to encounter abnormal anxiety, while respondents with high resilience scale usually possess normal anxiety. Respondents who had a low social support scale usually possess abnormal anxiety. Respondents who reported a high social support scale, reported to acquire abnormal anxiety. However, when comparing the range of anxiety scale between groups with low and high social support scale, respondents with low social support scale usually tend being more vulnerable to experience abnormal anxiety. 
Table 2. Chi-Square Test.

\begin{tabular}{lccc}
\hline Dependent Variables & \multicolumn{1}{c}{\begin{tabular}{c} 
Anxiety scale \\
Normal Anxiety \\
\cline { 2 - 4 }
\end{tabular}} & $\begin{array}{c}\text { Abnormal Anxiety } \\
\mathbf{n}(\boldsymbol{\%})\end{array}$ & $\boldsymbol{p}$-value \\
\hline Gender & $47(52,8)$ & $42(47,2)$ & 0,005 \\
Man & $51(34,2)$ & $98(65,8)$ & \\
Woman & & & 0,038 \\
Year of Study & $29(31,2)$ & $64(68,8)$ & \\
$\quad$ First & $30(45,5$ & $36(54,5)$ & \\
Second & $39(49,4)$ & $40(50,6)$ & \\
Third & & & \\
Resilience & $14(19,2)$ & $59(80,8)$ & 0,000 \\
$\quad$ Low & $84(50,9)$ & $81(49,1)$ & \\
High & & & \\
Social Support & $12(20,3)$ & $47(79,7)$ & \\
$\quad$ Low & $86(48)$ & $93(52)$ & \\
High & &
\end{tabular}

Note: $p$ value $=$ significance value. Source: Authors (2021).

Based on Table 3, The Chi-square test results based on gender stratification show that female respondents had higher anxiety scale than male respondents. In the three factors of study year, resilience, and social support, male respondents showed a non-significant relationship $(\mathrm{p}>0,05)$ with the anxiety scale. Female respondents showed a significant relationship $(\mathrm{p}<0,05)$ with the anxiety scale as two of three variables in resilience and social support. Therefore, female respondents tended to experience abnormal anxiety.

Table 3. Chi-Square test with stratification by gender.

\begin{tabular}{|c|c|c|c|c|}
\hline \multirow[t]{2}{*}{ Gender } & \multirow[t]{2}{*}{ Dependent Variables } & \multicolumn{3}{|c|}{ Anxiety scale } \\
\hline & & $\begin{array}{c}\text { Normal Anxiety } \\
n(\%)\end{array}$ & $\begin{array}{c}\text { Abnormal Anxiety } \\
n(\%)\end{array}$ & $p$-value \\
\hline \multirow[t]{10}{*}{ Male } & Year of Study & & & 0,193 \\
\hline & First & $11(39,3)$ & $17(60,7)$ & \\
\hline & Second & $14(63,6)$ & $8(36,4)$ & \\
\hline & Third & $22(56,4)$ & $17(43,6)$ & \\
\hline & Resilience & & & \\
\hline & Low & $6(33,3)$ & $12(66,7)$ & 0,072 \\
\hline & High & $41(57,7)$ & $30(42,3)$ & \\
\hline & Social Support & & & 0,313 \\
\hline & Low & $8(42,1)$ & $11(57,9)$ & \\
\hline & High & $39(55,7)$ & $31(44,3)$ & \\
\hline \multirow[t]{10}{*}{ Female } & Year of Study & & & 0,281 \\
\hline & First & $18(27,7)$ & $47(72,3)$ & \\
\hline & Second & $16(36,4)$ & $28(63,6)$ & \\
\hline & Third & $17(42,5)$ & $23(57,5)$ & \\
\hline & Resilience & & & 0,000 \\
\hline & Low & $8(14,5)$ & $47(85,5)$ & \\
\hline & High & $43(45,7)$ & $51(54,3)$ & \\
\hline & Social Support & & & 0,000 \\
\hline & Low & $4(10)$ & $36(90)$ & \\
\hline & High & $47(43,1)$ & $62(56,9)$ & \\
\hline
\end{tabular}

Note: $p$ value $=$ significance value. Source: Authors (2021).

The Kendall-tau correlation test revealed that the anxiety scale correlates with the four independent variables (as shown in Table 4). Gender possesses a positive correlation with anxiety scale ( $r=0.183, \mathrm{p}<0.01)$. Meanwhile, the variable year of study $(\mathrm{r}=-0.151, \mathrm{p}<0.05)$, social support $(\mathrm{r}=-0.243, \mathrm{p}<0.01)$, and resilience $(\mathrm{r}=-0.297, \mathrm{p}<0.01)$ exhibited a negative relationship with the anxiety scale. 
Table 4. Kendall-tau correlation test.

\begin{tabular}{llccccc}
\hline & & Gender & $\begin{array}{c}\text { Year of } \\
\text { Study }\end{array}$ & $\begin{array}{c}\text { Social } \\
\text { Support }\end{array}$ & Resilience & $\begin{array}{c}\text { Anxiety } \\
\text { scale }\end{array}$ \\
\hline Gender & r value & 1,000 & $-0,156$ & $-0,62$ & $-0,175^{* *}$ & $0,183^{* *}$ \\
Year of Study & $p$-value & - & 0,011 & 0,343 & 0,007 & 0,005 \\
& r value & $-0,156^{* *}$ & 1,000 & 0,038 & 0,056 & $-0,151^{*}$ \\
Social Support & $p$-value & 0,011 & - & 0,532 & 0,365 & 0,014 \\
& r value & $-0,62$ & 0,038 & 1,000 & $0,209 * *$ & $-0,243^{* *}$ \\
Resilience & $p$-value & 0,343 & 0,532 & - & 0,001 & 0,000 \\
& r value & $-0,175^{* *}$ & 0,056 & $-0,209^{* *}$ & 1,000 & $-0,297 * *$ \\
Anxiety scale & $p$-value & 0,007 & 0,365 & 0,001 & - & 0,000 \\
& r value & $0,183^{* *}$ & $-0,151^{*}$ & $-0,243^{* *}$ & $-0,297 * *$ & 1,000 \\
& $p$-value & 0,005 & 0,014 & 0,000 & 0,000 & - \\
\hline
\end{tabular}

Note: $\mathrm{r}=$ correlation coefficient value, $p$ value $=$ significance value. *significant correlation at 0.05 . ** significant correlation at 0.01. Source: Authors (2021).

\section{Discussion}

In accordance to findings of a survey of 238 medical students from Udayana University's Class of 2018-2020, it was shown that most respondents experienced normal anxiety scale with an amount of 167 respondents or $70.2 \%$. Normal anxiety can make it easier for an individual to find and solve the cause of his anxiety. (Stuart, 2014). This result was higher than the meta-analysis research carried out by Lasheras et al. (2020), which found that $28 \%$ of respondents experienced abnormal anxiety throughout the global pandemic. Basheti et al. (2021) discovered that $33.8 \%$ of medical students with abnormal anxiety throughout the global pandemic. The prevalence of anxiety scale were not significantly different from before the pandemic of COVID-19. According to Tian-Ci Quek et al. (2019), the prevalence of abnormal anxiety in medical students worldwide is $33.8 \%$. Mao et al. (2019) discovered that $27.22 \%$ of medical students in China experienced abnormal anxiety in their research on anxiety scales in medical respondents. In accordance to previous data, it was discovered that respondents with a normal anxiety outnumbered those with an abnormal anxiety scale.

As per results, gender factors had a significant relationship with anxiety scales $(r=0.183, p<0.01)$. Furthermore, the outcomes of stratification of the independent variables by gender revealed that female students experienced abnormal anxiety compared to male students. This is strengthened by a significant relationship between female students' resilience scale $(\mathrm{p}<0.01)$ and social support $(\mathrm{p}<0.01)$ and their anxiety scale. The findings of this research were founded on findings of Mayer et al. (2013), who discovered a connection between gender and anxiety in medical students. According to this study, women are more probable than men to experience anxiety ( $\mathrm{p}<0,001)$. According to Narmandakh et al. (2020), there was an influence between gender and anxiety, with women being 2.38 times more probable to experience anxiety than men $(\mathrm{OR}=2.38 ; \mathrm{p}<0.01)$. Furthermore, women tended to have negative perceptions of their social lives. This had the potential to occur because women were more competitive and ambitious to get good grades, causing women to experience abnormal anxiety (Christiansen, 2015).

The year of study factor produced significant results with the anxiety scale $(r=-0.151, \mathrm{p}<0.05)$. It was discovered that the lower the year of study, the greater anxiety scale, and the other way around. These findings were founded on research conducted by Achmad and Sukohar (2019), which found that early-level medical students were more probable to experience anxiety than final-level students $(\mathrm{p}<0,05)$. First-year students are still adjusting to the university environment, which includes living away from their parents, a new social environment, and very new medical course materials. Bassols et al. (2014) discovered that $30,8 \%$ of first-year medical students experienced anxiety more frequently than 9,4 percent of sixth-year medical students. When first-year medical students were compared to sixth-year students, they had a risk ratio of 3,27 times with more anxiety. First-year students tended to have difficulty adapting to college life both in academic and non-academic terms. 
As per result, resilience factor had a significant relationship with anxiety $(r=-0.297, \mathrm{p}<0.01)$, which explained that high resilience help decrease anxiety. Resilience is affected by self-efficacy, or an individual's conviction in his ability to achieve expected goals and survive life pressures. That's in connection with the theory foundation, which states that resilience is such a positive sign of mental health that can help avoid the occurrence of anxiety and depression (Hu, Zhang, \& Wang, 2015; Zhang et al., 2020). Resilience can enable medical students cope with the stresses of medical school. Good resilience can improve medical students' wellbeing in their everyday routines (Jordan et al., 2020). The theory was following research conducted by Hayat et al. (2021) explained as follows resilience serves as a preventive feature $(r=-0.391, p<0.01)$ from abnormal anxiety. Research conducted by Ran et al. (2020) also found significant results between resilience and anxiety ( $<<0,001)$. Furthermore, resilience had a significant correlation with depression and somatization as a preventive factor for these health issues. According to research conducted by Zhao et al. (2021), resilience is additionally a preventative measure for depression $(\mathrm{r}=-0.288$, $\mathrm{p} 0.001)$. A higher resilience scale can improve medical students' wellbeing, which involves good physical health, reduced anxiety, and high optimism.

The anxiety scale was also significantly influenced by social support $(r=-0.243, p<0.01)$ This meant that high social support can prevent individual from abnormal anxiety. This finding was coherent with the findings of a study a significant correlation between social support and anxiety, depression, and suicidal ideation in adolescents $(\mathrm{p}<0.01)$. This research also discovered a correlation between social support and anxiety $(\mathrm{OR}=0.78)$, severe depression $(\mathrm{OR}=0.53)$, suicidal ideation $(\mathrm{OR}=0.59)$, and attempted suicide $(\mathrm{OR}=0.60)$. This demonstrated that social support could really prevent a person from mental health issues such as anxiety, depression, suicidal ideation, and suicide attempts, especially if the person is preconditioned to mental health difficulties. (Scardera et al., 2020). According to Shao et al. (2020), social support is likewise a preventative measure against depression. $(r=-0.089, p<0.01)$ and anxiety $(r=-0.17, p<0.01)$. A strong social support can assist medical students in resolving difficulties like assignments and lectures. Furthermore, social support can provide students with feeling of safety by providing positive feelings, praise, and appreciation in their social environment (Dour et al., 2014).

Weakness of this research is that many factors that influence other anxiety were yet to be tested, such as family aspects for example, occupational status, family history of mental condition, and parenting; psychological aspects such as selfconfidence, stress levels, and past trauma; and biological aspects that consist of blood pressure, Body Mass Index (BMI), appearance, genetics,etc. Another limitation is the prospect of recall bias when filling out the questionnaires.

\section{Conclusion}

From the study's findings, four independent variables tested (gender, year of study, resilience scale, and social support scale) showed results that were significantly correlates with anxiety scale in Students of the Bachelor of Medicine and Medical Profession Study Program, Faculty of Medicine, Udayana University Class of 2018- 2020 in undergoing an online lecture learning system. This research can still be developed by referencing the shortcomings previously stated. The prospective cohort method should be utilized in future experiment to investigate the cause-and-effect relationship between anxiety scale and the aspects that influence them.

\section{References}

Achmad, F. R., Sukohar, A., \& others. (2019). Perbedaan Derajat Kecemasan Antara Mahasiswa Tahap Akademik Tingkat Awal dengan Tingkat Akhir di Fakultas Kedokteran Universitas Lampung. Jurnal Medula, 9(1).

Ahuja, K., Srivastava, P., Gul, A., \& Karnal, H. (2020). Resilience, Well Being and Marital Adjustment: a comparative study between those who are working from home to the ones who are working from their workplace. Indian Journal of Mental Health, 7(4).

Basheti, I. A., Mhaidat, Q. N., \& Mhaidat, H. N. (2021). Prevalence of anxiety and depression during COVID-19 pandemic among healthcare students in Jordan 
and its effect on their learning process: A national survey. PloS One, 16(4), e0249716.

Bassols, A. M., Okabayashi, L. S., Silva, A. B. da, Carneiro, B. B., Feijó, F., Guimaraes, G. C., \& Eizirik, C. L. (2014). First-and last-year medical students: is there a difference in the prevalence and intensity of anxiety and depressive symptoms? Brazilian Journal of Psychiatry, 36, 233-240.

Christiansen, D. M. (2015). Examining sex and gender differences in anxiety disorders. A Fresh Look at Anxiety Disorders, 17-49.

Damayanti, A. K. (2012). Gaya belajar ditinjau dari tipe kepribadian dan jenis kelamin. Persona: Jurnal Psikologi Indonesia, 1(2).

Dour, H. J., Wiley, J. F., Roy-Byrne, P., Stein, M. B., Sullivan, G., Sherbourne, C. D., \& Craske, M. G. (2014). Perceived social support mediates anxiety and depressive symptom changes following primary care intervention. Depression and Anxiety, 31(5), 436-442.

Harandi, T. F., Taghinasab, M. M., \& Nayeri, T. D. (2017). The correlation of social support with mental health: A meta-analysis. Electronic Physician, 9(9), 5212 .

Hayat, A. A., Choupani, H., \& Dehsorkhi, H. F. (2021). The mediating role of students' academic resilience in the relationship between self-efficacy and test anxiety. Journal of Education and Health Promotion, 10.

Hirsch, C. R., Mathews, A., Lequertier, B., Perman, G., \& Hayes, S. (2013). Characteristics of worry in generalized anxiety disorder. Journal of Behavior Therapy and Experimental Psychiatry, 44(4), 388-395.

Hu, T., Zhang, D., \& Wang, J. (2015). A meta-analysis of the trait resilience and mental health. Personality and Individual Differences, 76, $18-27$.

Jordan, R. K., Shah, S. S., Desai, H., Tripi, J., Mitchell, A., \& Worth, R. G. (2020). Variation of stress levels, burnout, and resilience throughout the academic year in first-year medical students. Plos One, 15(10), e0240667.

Kocalevent, R.-D., Berg, L., Beutel, M. E., Hinz, A., Zenger, M., Härter, M., \& Brähler, E. (2018). Social support in the general population: standardization of the Oslo social support scale (OSSS-3). BMC Psychology, 6(1), 1-8.

Lasheras, I., Gracia-Garcl'lia, P., Lipnicki, D. M., Bueno-Notivol, J., López-Antón, R., De La Cámara, C., \& Santabárbara, J. (2020). Prevalence of anxiety in medical students during the COVID-19 pandemic: a rapid systematic review with meta-analysis. International Journal of Environmental Research and Public Health, 17(18), 6603 .

Lee, K., Kim, D., \& Cho, Y. (2018). Exploratory factor analysis of the Beck anxiety inventory and the Beck depression inventory-II in a psychiatric outpatient population. Journal of Korean Medical Science, 33(16).

Mao, Y., Zhang, N., Liu, J., Zhu, B., He, R., \& Wang, X. (2019). A systematic review of depression and anxiety in medical students in China. BMC Medical Education, 19(1), 1-13.

Narmandakh, A., Roest, A. M., de Jonge, P., \& Oldehinkel, A. J. (2020). Psychosocial and biological risk factors of anxiety disorders in adolescents: A TRAILS report. European Child \& Adolescent Psychiatry, 1-14.

Papilaya, J. O., \& Huliselan, N. (2016). Identifikasi gaya belajar mahasiswa. Jurnal Psikologi, 15(1), 56-63.

Poudel-Tandukar, K., Chandler, G. E., Jacelon, C. S., Gautam, B., Bertone-Johnson, E. R., \& Hollon, S. D. (2019). Resilience and anxiety or depression among resettled Bhutanese adults in the United States. International Journal of Social Psychiatry, 65(6), 496-506.

Ran, L., Wang, W., Ai, M., Kong, Y., Chen, J., \& Kuang, L. (2020). Psychological resilience, depression, anxiety, and somatization symptoms in response to COVID-19: A study of the general population in China at the peak of its epidemic. Social Science \& Medicine, $262,113261$.

Sari, D. (2020). Peran Adaptif Tiga Universitas di Jabodetabek dalam Menghadapi Sistem Belajar Online Selama Pandemi Covid 19. Prosiding Seminar Nasional Hardiknas, 1, 25-32.

Scardera, S., Perret, L. C., Ouellet-Morin, I., Gariépy, G., Juster, R. P., Boivin, M., \& Geoffroy, M. C. (2020). Association of social support during adolescence with depression, anxiety, and suicidal ideation in young adults. JAMA Network Open, 3(12), 1-12. https://doi.org/10.1001/jamanetworkopen.2020.27491

Shao, R., He, P., Ling, B., Tan, L., Xu, L., Hou, Y., \& Yang, Y. (2020). Prevalence of depression and anxiety and correlations between depression, anxiety, family functioning, social support and coping styles among Chinese medical students. BMC Psychology, 8(1), 1-19.

Stuart, G. W. (2014). Principles and practice of psychiatric nursing-e-book. Elsevier Health Sciences.

Tian-Ci Quek, T., Tam, W.-S., X Tran, B., Zhang, M., Zhang, Z., Su-Hui Ho, C., \& others. (2019). The global prevalence of anxiety among medical students: a meta-analysis. International Journal of Environmental Research and Public Health, 16(15), 2735.

Zhang, J., Yang, Z., Wang, X., Li, J., Dong, L., Wang, F., \& Zhang, J. (2020). The relationship between resilience, anxiety and depression among patients with mild symptoms of COVID-19 in China: a cross-sectional study. Journal of Clinical Nursing, 29(21-22), 4020-4029.

Zhao, L., Sznajder, K., Cheng, D., Wang, S., Cui, C., Yang, X., \& others. (2021). Coping Styles for Mediating the Effect of Resilience on Depression Among Medical Students in Web-Based Classes During the COVID-19 Pandemic: Cross-sectional Questionnaire Study. Journal of Medical Internet Research, 23(6), e25259. 